https://doi.org/10.15407/scin16.04.025

POLISHCHUK, V.M., SHVOROV, S.A., TARASENKO, S.Ye., and ANTYPOV, I.O.

National University of Life and Environmental Sciences of Ukraine, 12, Heroiv Oborony Str., 03041, Kyiv, Ukraine, +38044527 8748, term_chair@nubip.edu.ua

\title{
INCREASING THE BIOGAS RELEASE DURING THE CATTLE MANURE FERMENTATION BY MEANS OF RATIONAL ADDITION OF SUBSTANDARD FLOUR AS A COSUBSTRATE
}

Introduction. The processing of livestock waste and agricultural production enables not only improving environmental safety, but also obtaining energy resources.

Problem Statement. Cош manure is used to produce biogas, but its yield is relatively low. One way to increase biogas yield is the joint fermentation of cow manure with substandard flour, which cannot be used as human food and as feed for farm animals. However, the flour content in the substrate, at which the biogas yield is maximum and there is no inhibition of the methane fermentation process, is not a solved issue.

Purpose. Increase biogas yield by adding substandard flour to a cow manure-based substrate.

Materials and Methods. Research of biogas yield during methane fermentation of substrate based on cow manure with the addition of substandard flour was carried out on a biogas plant consisting of a methane tank with a working volume of $30 \mathrm{l}$ and wet gasholder at periodic substrate loading and fermentation temperature $35^{\circ} \mathrm{C}$. The portion of the substrate included $1.7 \mathrm{~kg}$ of manure, $2.5 \mathrm{~kg}$ of water and 50, 100, $250 \mathrm{or} 500 \mathrm{~g}$ of flour. The composition of flour in the substrate was 1.2\%, 2.3\%, 5.6\% and 10.6\%. The dichotomy method was used to determine the optimal flour content in the substrate, provided the maximum biogas yield.

Results. The maximum biomethane release is $14.3 \mathrm{l} / \mathrm{kg}$ dry organic matter (DOM), at 1.2\% of the flour content in the substrate; $20.9 \mathrm{l} / \mathrm{kg}$ DOM, at 2.3\%; $19.2 \mathrm{l} / \mathrm{kg}$ DOM, at $5.6 \%$. At a content of $10.6 \%$ flour in the substrate, the biogas did not burn, fermentation quickly stopped. The optimum flour content in the substrate based on cow manure, in which the biogas yield increases 1.5 times, is 3.7\%.

Conclusions. Based on the conducted experimental studies, a model of biogas yield with gradual loading of the substrate was built and the optimal flour content in the substrate was determined, at which the maximum biogas yield is provided.

Keywords: biogas, methanetank, substandard flour, cattle manure, biogas plant, and methane fermentation.

Currently, one of the most important and urgent problems is processing of animal waste and agricultural production, not only for environmental safety, but also for obtaining energy resources. Based on the use of biogas technologies, cow manure is used, as a rule,

Цитування: Polishchuk V.M., Shvorov S.A., Tarasenko S.Ye., and Antypov I.O. Increasing the Biogas Release During the Cattle Manure Fermentation by Means of Rational Addition of Substandard Flour as a Cosubstrate. Nauka innov. 2020. V. 16, no. 4. P. 25-35. https://doi.org/10.15407/scin16.04.025 
for biogas and high-quality fertilizers. However, the biogas release during the fermentation of manure is relatively low due to a sufficiently large amount of crude fiber. One of the ways to increase the release of biogas is the joint fermentation of cow manure with substandard agricultural raw materials, which cannot be used as food for humans and animal feed. Therefore, to increase the release of biogas from manure, it is advisable to use cheaper raw materials such as waste from agricultural production and substandard products. Such wastes include wastes from biodiesel production [1; 2], molasses, vinasse, pulp, etc. By agricultural residues that increase yield of biogas can also include substandard flour. Analysis of recent research and publications on the grain waste disposal show that their anaerobic processing is the most effective for biogas production. According to the results of the study described in research [3], the release of biogas at a fermentation temperature of $38^{\circ} \mathrm{C}$ from substrates with the addition of rye bread is $0.459 \mathrm{l} / \mathrm{g}$ dry organic matter $(\mathrm{DOM})$, in research [4], various types of grain release - from $0.634 \mathrm{l} / \mathrm{g}$ DOM (for rye bread) to $0.943 \mathrm{l} / \mathrm{g}$ DOM (for wheat bread with egg and milk additives). As it is stated in research [5], the common fermentation of biowaste with the waste of wheat and rye bread with an organic loading rate of $14 \mathrm{~kg} / \mathrm{m}^{3}$ per day, was stable to their organic loading rate $\mathrm{kg} / \mathrm{m}^{3}$ per day and enabled producing 3 times more biogas. The release of methane at the fermentation of grain with DOM in the proportion of $1: 9,3: 7$ and $5: 5 \mathrm{is} 233 \mathrm{ml} / \mathrm{g}$ volatile substance (VS), $298 \mathrm{ml} / \mathrm{g} \mathrm{VS}$ and $344 \mathrm{ml} / \mathrm{g}$ VS [6]. In research [7] it is stated that the release of biogas when dry bread is added to the substrate is $650 \mathrm{l} / \mathrm{kg} \mathrm{VS}$ with a content of methane $47 \%$. As noted in research [8], as the result of co-digestion of grain waste with beer pellet and fish waste, there were obtained $671-763 \mathrm{ml} / \mathrm{g}$ VS biogas and 441-482 $\mathrm{ml} / \mathrm{g}$ VS methane. The time of hydraulic maintenance and the time of technical splitting were $21.0-23.8$ days and $40.5-52.8$ days, respectively.
In research [9], the effect of feed (grains, seeds of oilseeds, husk) on methane release was investigated. It was found that the largest daily release of methane was obtained when feeding cattle with grain and products of its processing, namely: wheat flour $(11.6 \mathrm{ml} / \mathrm{g}$ dry matter (DM)), wheat grain (11.4 ml/g DM), maize corn (10.3 ml/g DM), oat grains, and $(6.9 \mathrm{ml} / \mathrm{g} \mathrm{DM})$. It was found in research [10] that the release of biogas during the fermentation of a substrate with the addition of boiled rice to a methane tank of 100 liters is $0.6 \mathrm{~m}^{3} /$ day, which is higher than with the addition of potato peels $\left(0.44 \mathrm{~m}^{3}\right.$ day $)$, orange peel $\left(0.32 \mathrm{~m}^{3} /\right.$ day $)$ and a mixture of these three types of raw materials $\left(0.21 \mathrm{~m}^{3} /\right.$ day $)$. The release of biogas from the substrate by the addition of flour was low, $0.01-0.04 \mathrm{~m}^{3} /$ day. In research [11], there was compared the release of biogas with the addition of flour waste after cleaning the mill, ground chopped jetropha, crushed paper mass to the substrate on the basis of cow manure. The largest biogas release (3.2 l/day) and methane (66.3\%) were obtained by adding flour to the substrate in the proportion $\mathrm{C}: \mathrm{N}=27: 1$. Comparison of the biogas release after adding to the substrate on the basis of cow manure of grain, fruits and vegetables at a temperature of $27^{\circ} \mathrm{C}$ to $36^{\circ} \mathrm{C}$ and a $\mathrm{pH}$ of 6.5 to 7.5 is described in research [12]. The largest release of methane was obtained from the substrate with the addition of grain inclusions ( $2546 \mathrm{ml}$ ), whereas with the addition of fruit waste, $2000 \mathrm{ml}$ was obtained, vegetable waste $-1468 \mathrm{ml}$. In research [13, 5], the release of biogas from barley grains is estimated as $353-658 \mathrm{~m}^{3} / \mathrm{t} \mathrm{VS}$, from wheat as $384-426 \mathrm{~m}^{3} / \mathrm{t} \mathrm{VS}$, from triticale as $337-555 \mathrm{~m}^{3} / \mathrm{t} \mathrm{VS}$, from oats as $250-295 \mathrm{~m}^{3} / \mathrm{t}$ VS, from sorghum as $295-372 \mathrm{~m}^{3} / \mathrm{t} \mathrm{VS}$, and from rye as $283-492 \mathrm{~m}^{3} / \mathrm{t}$ VS. The release of methane from processed brewing grain, as stated in researches [14] and [15], is $0.284 \mathrm{l} / \mathrm{g}$ of HSC. According to [16], the total methane release of processed brewing grain without preliminary treatment is $409.8 \mathrm{~m}^{3} / \mathrm{t} \mathrm{VS}$, whereas the release of pre-heated at a temperature of $100-200{ }^{\circ} \mathrm{C}$ is 
$467.6 \mathrm{~m}^{3} / \mathrm{t}$ VS. The results of the studies described in research [17] showed that the potential of biogas from the processed brewing grain is $120 \mathrm{l} / \mathrm{kg}$. In a single-stage system, the release of biogas from unprocessed grain $(87.4 \mathrm{l} / \mathrm{kg})$ is almost equal to the release of biogas from pre-processed grain $(89.1 \mathrm{l} / \mathrm{kg})$, while the release of methane was $51.9 \mathrm{l} / \mathrm{kg}$ and $55.3 \mathrm{l} / \mathrm{kg}$ respectively, and biodegradation was 62.0 and $62.2 \%$. In the two-stage process, preliminary grain cultivation showed better results, with a $103.2 \mathrm{l} / \mathrm{kg}$ of biogas release and $73,6 \%$ biodegradation, whereas the biogas release from untreated grain was $89.1 \mathrm{l} / \mathrm{kg}$ with a biodegradation of $63.5 \%$. In the two-stage process, methane releases from untreated and preprocessed raw materials were identical -58.7 l/kg. The average specific production of biogas, as stated in [18], is $414 \pm 32 \mathrm{l} / \mathrm{kg}$ of DM, with a biomethane release of $224 \pm 34 \mathrm{l} / \mathrm{kg}$ of DM. The release of biogas from processed grains, obtained in the studies described in [19], is $0.596 \mathrm{~m}^{3} / \mathrm{kg} \mathrm{VS}$ with $65 \%$ of methane content.

On the other hand, as noted in [20], the lowest costs for processing cow manure are provided during anaerobic digestion, and when selling energy from exhaust gases to a farm, one can get from 6.8 to $13.6 \mathrm{~m}^{3}$ /day of warm water [21]. In [22], it was shown that biogas release from manure is $450 \mathrm{~m}^{3} / \mathrm{t} \mathrm{VS}$, which is significantly less compared to biogas release during the fermentation of food waste $\left(660 \mathrm{~m}^{3} / \mathrm{t} \mathrm{VS}\right)$. When fermenting cattle manure compared with corn silage, it produced less biogas release, which was also confirmed in [23]. According to [24], the release of biogas during the fermentation of cow manure $\left(0.31 \mathrm{~m}^{3} / \mathrm{kg} \mathrm{VS}\right)$ is higher compared to the digestion of food waste $\left(0.17 \mathrm{~m}^{3} / \mathrm{kg}\right.$ VS $)$. The high release of methane $(1040 \mathrm{ml} / \mathrm{g}$ VS versus $118 \mathrm{ml} / \mathrm{g} \mathrm{VS}$ for monofermentation of food waste) gives the ratio of fats and food waste 50:50, with a content of $85 \%$ lipids and 15\% protein, as noted in [25].

In the case of joint fermentation of processed brewing grain and phytomass of the artichoke under thermophilic conditions, the release of methane was $6-8 \mathrm{l} / 100 \mathrm{~g}$ of processed brewing grain with its loading of $50 \mathrm{~g} / \mathrm{l}$ and $9-11 \mathrm{l} / 100 \mathrm{~g}$ of processed brewing grain when loaded $100 \mathrm{~g} / \mathrm{l}$ [26]. According to [27], the highest biochemical methane potential of the processed brewing grain is $515 \mathrm{l} / \mathrm{kg}$.

Thus, there is a need for further research to determine and justify the modes of fermentation of cereals and grain waste by means of fermentation of substandard flour with cow manure. The purpose of the article is to increase the release of biogas using the rational mode of the manure fermentation with the addition of substandard flour as a co-substrate. To achieve this goal it is necessary to solve the following tasks:

1. To determine the content of DM, DOM and substrate moisture based on cow manure with the addition of flour;

2. To carry out an experimental study of the biogas release during the fermentation of cow manure with the addition of flour;

3. To construct a model of the biogas release and to determine the optimal composition of the flour been gradually loaded for the fermentation of cow manure.

4. Justify recommendations regarding the content of flour in the substrate for the gradual loading of the methane tank.

Studies were conducted on a laboratory biogas plant, with a volume of 301 (Fig. 1, $a, b$ ). Determination of biogas release was carried out with the help of a wet gasholder. In doing so, the heating of the digester is provided by a water jacket with an electric heater, which is placed between the outer and the inner hull. The substrate is pumped into the active zone of the inner shell through a pipe that almost reaches the bottom. At the same time, the processed digestate is fed through a pipe, which is located at the level of the substrate and biogas boundary. Refueling of the digester is carried with regard for not less than $1 / 3$ of the processed digestate with uterine bacteria culture in it. The release of biogas is recorded on a scale, graduated in centimeters, of a raised cylinder gauge of a wet gasholder. The calorific value of biogas is determined by burning 


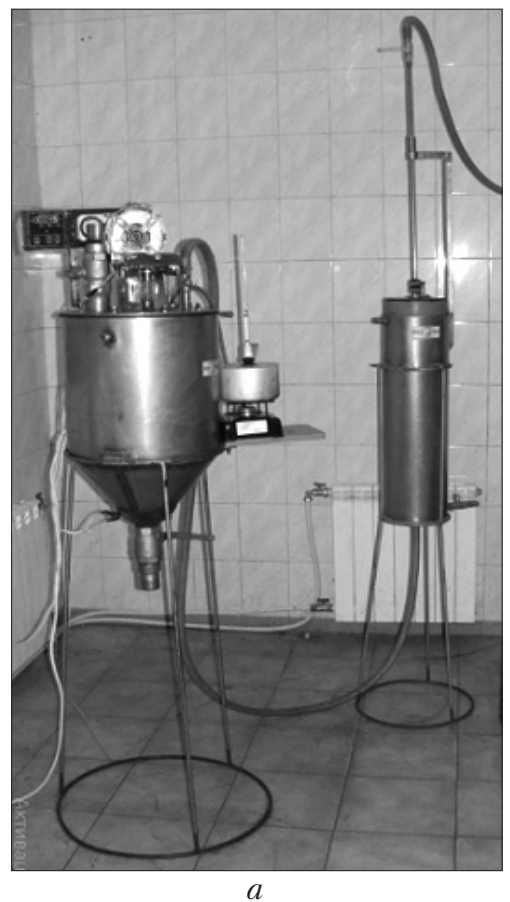

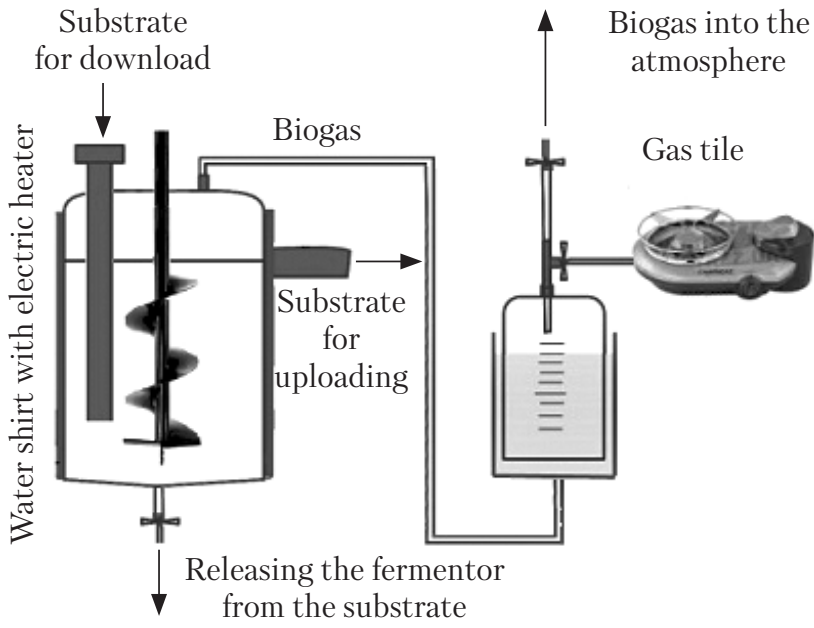

$b$

Fig. 1. Laboratory biogas plant: $a-$ appearance; $b-$ plant layout

it on a gas stove, while heating the water in the calorific value measurer.

The substrate is prepared by mixing cow manure with water and flour added to it. The methane tank was filled with the substrate by $3 / 4$ with a periodic loading mode.

Experimental study of the biogas release during the fermentation of cow manure with the addition of flour was carried out at a fermentation temperature of $35^{\circ} \mathrm{C}$ (in mesophilic mode). A methane tank was loaded with a portion of the substrate, which consisted of $1.7 \mathrm{~kg}$ of cow manure, $2.5 \mathrm{~kg}$ of water and $50,100,250$ or $500 \mathrm{~g}$ of flour. Meanwhile, the content of flour in the substrate was 1.2, 2.3, 5.6 and $10.6 \%$.

Determination of the content of DM, DOM and substrate moisture on the basis of cow manure with the addition of flour. In the solid fraction of cow manure there is $16.4 \%$ of DM [28], of which about $80 \%$ is DOM [29].

Then the mass of dry matter of cow manure, which is part of the substrate, is:

$$
M_{D M s}=\frac{1.7 \cdot 16.5}{100}=0.2805 \mathrm{~kg}
$$

and the mass of dry organic matter of cow manure, which is part of the substrate, according to the formula (2):

$$
M_{\text {DOMs }}=\frac{0.2805 \cdot 80}{100}=0.2244 \mathrm{~kg} .
$$

The highest grade wheat flour contains $85 \%$ of dry matter, of which $99.5 \%$ is organic matter [30].

Then the mass of dry matter of flour, which is part of the substrate, according to the formula (1) is:

at the weight of flour $50 \mathrm{~g}$ :

$$
M_{D M s}=\frac{0.05 \cdot 85}{100}=0.0425 \mathrm{~kg} \text {; }
$$

at the weight of flour $100 \mathrm{~g}$ :

$$
M_{D M s}=\frac{0.1 \cdot 85}{100}=0.085 \mathrm{~kg} \text {; }
$$

at the weight of flour $250 \mathrm{~g}$ :

$$
M_{D M s}=\frac{0.25 \cdot 85}{100}=0.2125 \mathrm{~kg}
$$

at the weight of flour $500 \mathrm{~g}$ :

$$
M_{D M s}=\frac{0.5 \cdot 85}{100}=0.425 \mathrm{~kg} \text {; }
$$

The mass of dry matter of flour, which is part of the substrate, according to the formula (2) is: 
at the weight of flour $50 \mathrm{~g}$ :

$$
M_{D O M s}=\frac{0.0425 \cdot 99.5}{100}=0.0423 \mathrm{~kg}
$$

at the weight of flour $100 \mathrm{~g}$ :

$$
M_{\text {DOMs }}=\frac{0.085 \cdot 99.5}{100}=0.0846 \mathrm{~kg}
$$

at the weight of flour $250 \mathrm{~g}$ :

$$
M_{D O M S}=\frac{0.2125 \cdot 99.5}{100}=0.2114 \mathrm{~kg}
$$

at the weight of flour $500 \mathrm{~g}$ :

$$
M_{\text {DOMs }}=\frac{0.425 \cdot 99.5}{100}=0.0429 \mathrm{~kg} \text {. }
$$

The total dry organic matter of the substrate is defined as the sum of dry organic matter of cow manure and flour:

at the weight of flour $50 \mathrm{~g}$ :

$$
0.2244+0.0423=0.2667 \mathrm{~kg} \text {, }
$$

or

$$
\frac{0.2667 \cdot 100}{1.7+0.05+2.5}=6.3 \% \text { of substrate mass; }
$$

at the weight of flour $100 \mathrm{~g}$ :

$$
0.2244+0.0846=0.309 \mathrm{~kg} \text {, }
$$

or

$$
\frac{0.309 \cdot 100}{1.7+0.1+2.5}=7.2 \% \text { of substrate mass; }
$$

at the weight of flour $250 \mathrm{~g}$ :

$$
0.2244+0.2114=0.4358 \mathrm{~kg}
$$

or

$$
\frac{0.4358 \cdot 100}{1.7+0.25+2.5}=9.8 \% \text { of substrate mass; }
$$

at the weight of flour $500 \mathrm{~g}$ :

$$
0.2244+0.4229=0.6473 \mathrm{~kg},
$$

or

$$
\frac{0.6473 \cdot 100}{1.7+0.25+2.5}=13.8 \% \text { of substrate mass. }
$$

The content of DOM of flour in DOM of substrate is:

at the weight of flour $50 \mathrm{~g}$ :

$$
\frac{0.0423 \cdot 100}{0.2667}=15.9 \% \text {; }
$$

at the weight of flour $100 \mathrm{~g}$ :

$$
\frac{0.0846 \cdot 100}{0.309}=27.4 \%
$$

at the weight of flour $250 \mathrm{~g}$ :

$$
\frac{0.2114 \cdot 100}{0.4358}=48.5 \% \text {; }
$$

at the weight of flour $500 \mathrm{~g}$ :

$$
\frac{0.4229 \cdot 100}{0.6473}=65.3 \% \text {. }
$$

Relative moisture of the solid fraction of cow manure is $84 \%$ [31], flour - 15\% [30], water $100 \%$. Relative moisture of the three-component substrate of this type is:

at the weight of flour $50 \mathrm{~g}$ :

$$
W_{S}=\frac{1.7 \cdot 84+0.05 \cdot 15+2.5 \cdot 100}{1.7+0.05+2.5}=92.6 \% ;
$$

at the weight of flour $100 \mathrm{~g}$ :

$$
W_{S}=\frac{1.7 \cdot 84+0.1 \cdot 15+2.5 \cdot 100}{1.7+0.1+2.5}=91.7 \% \text {; }
$$

at the weight of flour $250 \mathrm{~g}$ :

$$
W_{S}=\frac{1.7 \cdot 84+0.25 \cdot 15+2.5 \cdot 100}{1.7+0.25+2.5}=89.1 \% ;
$$

at the weight of flour $500 \mathrm{~g}$ :

$$
W_{S}=\frac{1.7 \cdot 84+0.5 \cdot 15+2.5 \cdot 100}{1.7+0.5+2.5}=85.2 \% .
$$

Experimental study of biogas release during the fermentation of cow manure with the addition of flour. The study of the substrate fermentation on the basis of cow manure with the addition of flour as a co-substrate was carried out to check the theses given in the papers [32, 69], [32, 88], [33, 81-82] that:

- when grains of cereals are fermented, a high release of biogas at the level of $620 \mathrm{~m}^{3} / \mathrm{t}$ of substrate with a methane content of about $50 \%$ is provided;

- grain (or grain products) decomposes very quickly, resulting in rapid peroxidation; due to the high content of proteins in the grain, the risk of delay in the bacteria development because of the ammonia action also increases.

In addition to that, quantitative indicators of the addition of flour to methane tank are currently not sufficiently complete for obtaining maximum volumes of biogas, and thus require additional research. 


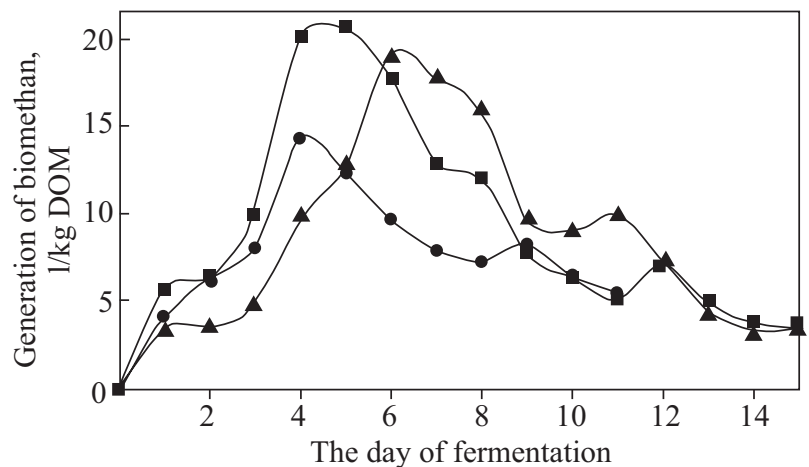

The content of flour in the substrate, $\%:-1.2 ; \_-2.3 ;-5.6$

Fig. 2. The biogas release during the process of cow manure fermentation with an addition of flour at a temperature of $35^{\circ} \mathrm{C}$

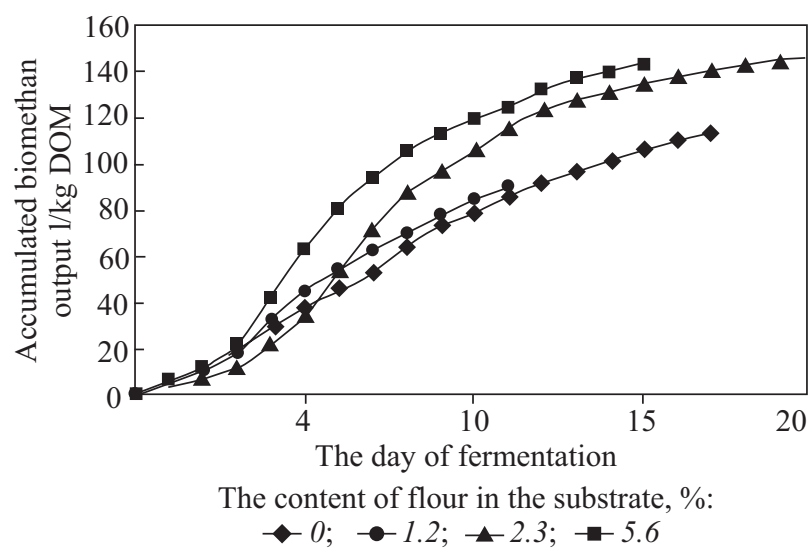

Fig.3. Accumulated biogas release during the fermentation of the cow manure and flour mixture at a temperature of $35^{\circ} \mathrm{C}$

Experimental study of the biogas release during the fermentation of cow manure with the addition of flour was carried out at a fermentation temperature of $35{ }^{\circ} \mathrm{C}$ (in mesophilic mode). A methane tank was loaded with a portion of the substrate, which consisted of $1.7 \mathrm{~kg}$ of cow manure, $2.5 \mathrm{~kg}$ of water and 50,100, 250 or $500 \mathrm{~g}$ of flour. In this case, the content of flour in the substrate was $1.2,2.3,5.6$ and $10.6 \%$, and the substrate moisture was $92.6,91.7,89.1$ and $85.2 \%$ respectively

The research results are presented in Fig. 2.

As it can be seen in Fig. 2, with the fermentation of cow manure and flour mixture in all concentrations investigated, the first day of the fer- mentation fixes the maximum release of biogas, which subsequently gradually decreases. There is also diaxis. In some cases, it is clearly expressed, in others it is barely noticeable, for example, when the content of flour in the substrate is $1.2 \%$.

The maximum biomethane release is $14.3 \mathrm{l} / \mathrm{kg}$ $\mathrm{DOM}$, at $1.2 \%$ flour content in the substrate, $20.9 \mathrm{l} / \mathrm{kg} \mathrm{DOM}$, at $2.3 \%$ flour content, $19.2 \mathrm{l} / \mathrm{kg}$ DOM, at $5.6 \%$ flour content, and biogas did not burn, at $10.6 \%$ flour content.

The conversion coefficient of biomethane release from the dimension of $1 / \mathrm{kg}$ DOM to the dimension $1 / \mathrm{kg}$ is $15.936 \mathrm{~kg} / \mathrm{kg} \mathrm{DOM}$, at $1.2 \%$ of the flour content in the substrate, $13.917 \mathrm{~kg} / \mathrm{kg}$ COP, at $2.3 \%$ flour content, and $10.210 \mathrm{~kg} / \mathrm{kg}$ DOM, at $5.6 \%$ flour content.

Accumulated biomethane release during the fermentation of the cow manure and flour mixture is shown in Fig. 3, from which it is evident that the total release of biomethane during the fermentation of the cow manure and flour mixture for 11 days of fermentation is: $89.9 \mathrm{l} / \mathrm{kg}$ DOM with a content of flour in the substrate $1.2 \%, 124.3 \mathrm{l} / \mathrm{kg}$ DOM at the content of flour in the substrate is $2.3 \%, 115.9 \mathrm{l} / \mathrm{kg}$ DOM with a content of flour in the substrate $5.6 \%$.

Compared to pure cow manure, the release of biomethane during the fermentation of the mixture of cow manure and flour is 1.5-2 times higher in almost all investigated proportions (except for the content of flour in the substrate 10.6\%). Accumulated release of biomethane during the fermentation of cow manure with the addition of flour at a fermentation temperature of $35{ }^{\circ} \mathrm{C}$ is approximated by a polynomial (3):

$$
Q_{\text {accumul }}=b_{n}+t^{n}+b_{n-1}+t^{n-1}+b_{1}+t+b_{0}
$$

where $Q_{\text {accumul }}-$ accumulated biomethane release, $1 / \mathrm{kg}$ DOM; $b$ - polynomial coefficients; $t$ - time of fermentation, days; $n$ - the degree of polynomial.

The coefficients of polynomial (3) are given in Table 1.

The determination coefficients of the approximated curves (3), with the coefficients of the polynomial, are given in the Table 1, defined by 
[34], approaching a unit, indicating that the obtained regression equations accurately reflect the experimental data. When checking on Fisher's criterion [35] the significance of the determination coefficients is identified. Verification by Student's Criteria [35] showed that all coefficients of polynomials (3), Tabl. 1, are significant.

Biogas obtained during the fermentation of flour added to cow manure (with a content of flour in the substrate 1.2, 2.3 and 5.6\%) in the first 2-3 days of fermentation (when the first peak of biogas release is observed) does not burn, on the next day it burns badly. The heat of combustion of biogas with the content of flour in the substrate $1.2 \%$ after the stabilization of the methane content is $13-14 \mathrm{MJ} / \mathrm{m}^{3}$, with the content of flour in the substrate $2.3 \%$ it reaches $17.5 \mathrm{MJ} / \mathrm{m}^{3}$, with the content of flour in the substrate $5.6 \%$ up to $20 \mathrm{MJ} / \mathrm{m}^{3}$. At the contents of the flour in the substrate $10.6 \%$ biogas burning did not occur during the whole time of the experiment.

Thus at the release of biogas, the optimal amount of flour added to the substrate is $2.3 \%$. When increasing the content of flour in the substrate over $5.6 \%$, the burning stops.

Biomethane release model of the gradual loading during the fermentation of cow manure with the addition of flour. In. Fig. 2 it is seen that 1, the maximum release of biomethane at a fermentation temperature of $35^{\circ} \mathrm{C}$ is $14.31 / \mathrm{kg} \mathrm{DOM}$, at $2 \%$ flour content in the substrate, $-20.9 \mathrm{l} / \mathrm{kg}$ DOM, at 2.3\% flour content, and 19.2 1/ kg DOM, at $5,6 \%$ flour content; at $10.6 \%$, biogas did not burn, in the absence of flour in the substrate, and the yield of biomethane was $9.3 \mathrm{l} / \mathrm{kg}$ DOM. Mo-

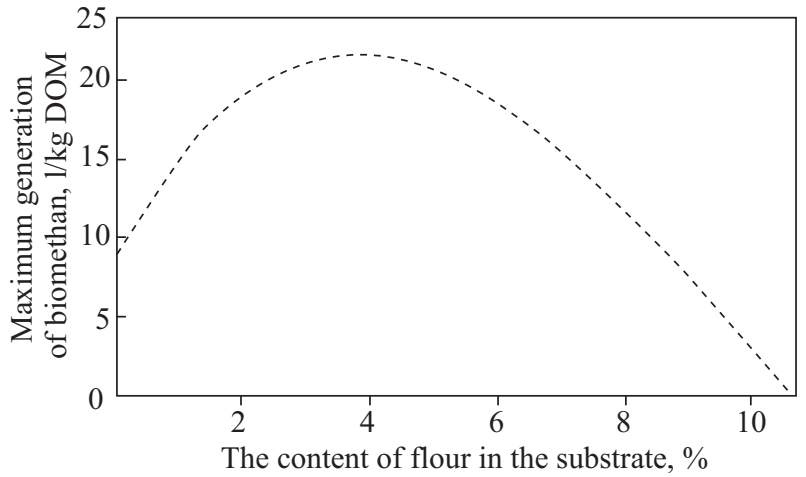

Fig. 4. Modelled release of biogas during the fermentation of cow manure with the addition of flour for the gradual loading of the methane tank

delled release of biomethane during the fermentation of cattle manure with the addition of flour for the gradual load of methane during fermentation temperature of $35^{\circ} \mathrm{C}$, as obtained on the basis of the experimental results of biogas release during periodic load, is given in Fig. 4.

Modelled release of biomethane during the fermentation of cow manure with the addition of flour for the gradual loading of methane tank at a fermentation temperature of $35^{\circ} \mathrm{C}$ is approximated by the mathematical equation:

$$
\begin{aligned}
& Q_{\text {mod }}=0.0381 \cdot x^{3}-1.1629 \cdot x^{2}+ \\
& +7.2235 \cdot x+8.74, R^{2}=0.9854,
\end{aligned}
$$

where $Q_{\text {mod }}$ is modelled biomethane release for quasi-continuous methane tanks loading system, $1 / \mathrm{kg} \mathrm{DOM} ; x$ is the content of flour in the substrate, $\%$.

The approximation equation is valid with the content of flour in the substrate not more than $7 \%$.

Table 1. Coefficients of a Polynomial That Describes the Average Accumulated Release of Biomethane During the Fermentation of Cow Manure with the Addition of Flour

\begin{tabular}{|c|c|c|c|c|c|c|c|}
\hline \multirow{2}{*}{ № } & \multirow{2}{*}{$\begin{array}{c}\text { Flour content in the } \\
\text { substrate, \% }\end{array}$} & \multicolumn{5}{|c|}{ The coefficients of a polynomial } & \multirow{2}{*}{$R^{2}$} \\
\cline { 3 - 7 } & & $b_{4}$ & $b_{3}$ & $b_{2}$ & $b_{1}$ & $b_{0}$ & \\
\hline 1 & 0 & - & -0.0183 & 0.3067 & 6.7662 & -1.68 & 0.999 \\
2 & 1.2 & 0.016 & -0.4327 & 3.6303 & -0.7284 & 0.42 & 0.9989 \\
3 & 2.3 & 0.015 & -0.503 & 4.9478 & -2.0793 & 0.59 & 0.9981 \\
4 & 5.6 & 0.0053 & -0.2459 & 3.3486 & -3.6649 & 1.06 & 0.9975 \\
\hline
\end{tabular}


As can be seen in Fig. 4, when the flour is added to the substrate, the biomethane release increases and reaches the maximum value at the content $2.3 \%$ of flour in the substrate. When more flour is added to the substrate, the biomethane release begins to decrease, and when the flour content reaches $10.6 \%$ stops.

Determination coefficient of the approximated function (4), determined by [34] that describes the modelled release of biomethane during the fermentation of cow manure with the addition of flour for the gradual loading of the methane at a fermentation temperature of $35^{\circ} \mathrm{C}$, approaches a one, indicating that the obtained regression equation accurately reflects experimental data. When checking by Fisher's criterion [35] the significance of the determination coefficient was introduced. Verification by Student's Criteria [35] showed that the coefficients of the polynomial are significant.

To find the extremum (maximum) of function (4), we use the half-division method (dichotomy method) using the Internet calculator [36] in the following formulation of this problem:

Required in the interval $0<x<7$ (watch Fig. 4) to find the maximum of function $f(x)=$ $=-0.038 x^{3}-1.16 x^{2}+7.22 x+8.74$ when the accuracy of the solution is $\varepsilon_{n}<0.1$ and the increment step $\delta=0.01$. For this purpose, the objective function (4) can be represented as: $F(\max )=$ $=-F(\min )$, that is:

$F_{(\max )}=-0.0385 \cdot x^{3}+1.16 \cdot x^{2}-7.22 \cdot x-8.74$.

Solution of the mathematical problem using dichotomy method: choose the increment step $\delta=0.01$.
Suppose $a_{1}=a, b_{1}=b$. Thus:

$$
\begin{aligned}
& x_{1}=(0+7-0.01) / 2=3.495, \\
& x_{1}=(0+7+0.01) / 2=3.505 .
\end{aligned}
$$

Calculate $f\left(x_{1}\right)=-21.40782655, f\left(x_{1}\right)=$ -21.41266031 ,

$\varepsilon_{1}=\frac{b-a-\delta}{2^{n}}+\frac{\delta}{2}=\frac{7-0-0.01}{2^{1+1}}+\frac{0.01}{2}=1.7525$.

Iteration №1. Since $f\left(x_{11}\right)>f\left(x_{12}\right)$, то $a_{2}=3.505$, $b_{2}=b_{1}$.

$$
\begin{gathered}
\varepsilon_{2}=\frac{7-3.505-0.01}{2^{2+1}}+\frac{0.01}{2}=0.440625, \\
x_{11}=(3.505+7-0.01) / 2=5.2475, \\
x_{12}=(3.505+7-0.01) / 2=5.2575, \\
f\left(x_{21}\right)=-20.1287, f\left(x_{22}\right)=-20.1103
\end{gathered}
$$

Iteration №2. Since $f\left(x_{21}\right)>f\left(x_{22}\right)$, то $b_{3}=5.2475$, $a_{3}=a_{2}$.

$$
\begin{gathered}
\varepsilon_{3}=\frac{5.2475-3.505-0.01}{2^{3+1}}+\frac{0.01}{2}=0.11328125, \\
x_{21}=(3.505+5.2475-0.01) / 2=4.37125, \\
x_{22}=(3.505+5.2475+0.01) / 2=4.38125, \\
f\left(x_{31}\right)=-21.2775, f\left(x_{32}\right)=-21.2699 .
\end{gathered}
$$

Iteration №3. Since $f\left(x_{31}\right)>f\left(x_{32}\right)$, то $b_{4}=4.3713$, $a_{4}=a_{3}$.

$$
\begin{gathered}
\varepsilon_{3}=\frac{4.37125-3.505-0.01}{2^{4+1}}+\frac{0.01}{2}=0.03175781, \\
x_{31}=(3.505+4.37125-0.01) / 2=3.933125, \\
x_{32}=(3.505+4.37125+0.01) / 2=3.943125, \\
f\left(x_{41}\right)=-21.4796, f\left(x_{42}\right)=-21.478 .
\end{gathered}
$$

Iteration №4. Since $f\left(x_{41}\right)>f\left(x_{42}\right)$, то $b_{5}=3.9331$, $a_{5}=a_{4}$.

$\varepsilon_{3}=\frac{3.933125-3.505-0.01}{2^{5+1}}+\frac{0.01}{2}=0.0115332$,

Table 2. Results of the Step-By-Step Solution of the Problem Using the Dichotomy Method

\begin{tabular}{|r|c|c|c|c|c|c|c|c|}
\hline $\mathrm{n}$ & $a_{n}$ & $b_{n}$ & $b_{n}-a_{n}$ & $x_{n 1}$ & $x_{n 2}$ & $F\left(x_{n 1}\right)$ & $F\left(x_{n 2}\right)$ & $\varepsilon_{n}$ \\
\hline 1 & 0 & 7 & 3.5 & 3.495 & 3.505 & -21.4078 & -21.4127 & 1.7525 \\
2 & 3.505 & 7 & 3.495 & 5.2475 & 5.2575 & -20.1287 & -20.1103 & 0.4406 \\
3 & 3.505 & 5.2475 & 1.7425 & 4.3713 & 4.3813 & -21.2775 & -21.2699 & 0.1133 \\
4 & 3.505 & 4.3713 & 0.8663 & 3.9331 & 3.9431 & -21.4796 & -21.478 & 0.03176 \\
54 & 3.505 & 3.9331 & 0.4281 & 3.7141 & 3.7241 & -21.4792 & -21.4807 & 0.01153 \\
\hline
\end{tabular}


$x_{31}=(3.505+3.933125-0.01) / 2=3.7140625$,

$x_{32}=(3.505+3.933125+0.01) / 2=3.7240625$,

$$
f\left(x_{51}\right)=-21.4792, f\left(x_{52}\right)=-21.4807 \text {. }
$$

The remaining calculations are summarized in Table 2.

Since at iteration No. 5 the condition is satisfied for a given accuracy of the result of the problemsolving,i.e. $|-21.47881363-(-21.47994443)|$ $\leq 0.1$, we find $\mathrm{x}$ as the middle of the interval $[a, b]$ : $x=(3.933125+3.505) / 2=3.7190625$. Thus, provided

$$
\begin{gathered}
\varepsilon_{n}=\frac{b-a-\delta}{2^{n}}+\frac{\delta}{2}=\frac{3.933125-3.505-0.01}{2^{4+1}}+ \\
+\frac{0.01}{2}=0.440625, \\
x=3.7190625, f(x)=21.47994443 .
\end{gathered}
$$

According to experimental data, for the gradual loading of methane tank, the optimum content of flour in the substrate is $3.7 \%$. According to the proposed model, it is possible to recommend rational content of flour in the substrate within the limits of $2.3-4.2 \%$.

On the basis of the research conducted the following results were obtained:

- the maximum release of biomethane for the periodic loading of the substrate is determined, which is $14.3 \mathrm{l} / \mathrm{Kg} \mathrm{DOM}$ at $1.2 \%$ of the flour con- tent in the substrate; $20.9 \mathrm{l} / \mathrm{kg} \mathrm{DOM}$ at $2.3 \%$; $19.2 \mathrm{l} / \mathrm{kg} \mathrm{DOM}$ at $5.6 \%$; adding $10.6 \%$ of flour to the substrate causes the fermentation to stop;

- a new model of biomethane release was developed during the fermentation of cow manure with the addition of flour-based Newton polynomial of the second order and a new approach was developed for optimizing fermentation of cow manure with the addition of flour based on the use of the dichotomy method;

- an optimal content of flour in the substrate is determined for the gradual loading of the methane tank, that is $3,7 \%$;

- the recommendations on the rational content of flour in the substrate within the limits of $2.3-4.2 \%$ were substantiated, within these limits the biomethane release during the fermentation of the mixture of cow manure and flour is increased by 1.5 times.

Prospects for further research in this direction are the preliminary rotor-pulsation (cavitational) treatment of non-standard grain and its mixing with cow manure and other agricultural waste to increase the release of biomethane. A promising direction is also the development of a method for intensifying anaerobic fermentation processes [37], based on the effect of a rotating magnetic field on aqueous substrates of biomass waste.

\section{REFERENCES}

1. Polishchuk, V., Tarasenko, S., Antypov, Je., Kozak, N., Zhyltsov, A., Okushko, O. (2020). Study of Methods of Biodiesel Neutralization with Aqueous Solution of Lymonic Acid. For results 6-th International Conference: Renewable Energy Sources (ICoRES 2019) (June 12-14, 2019, Krynica, Poland), E3S Web of Conferences. 154. 02007. doi: 10.1051/ e3sconf/202015402007.

2. Polishchuk, V., Tarasenko, S., Antypov, Je., Kozak, N., Zhyltsov, A., Bereziuk, A. (2020). Investigation of the Efficiency of Wet Biodiesel Purification. For results 6-th International Conference: Renewable Energy Sources (ICoRES 2019) (June 12-14, 2019, Krynica, Poland), E3S Web of Conferences. 154. 02006. doi: 10.1051/e3sconf/202015402006.

3. Dubrovskis, V., Plume, I., Straume, I. (2018, May). Methane production from bread kursu and potatoes vineta waste and effect of catalyst metaferm. Engineering for Rural Development. For results 17-th International Scientific Conference Engineering for Rural Development, ERD (May 23-25, 2018, Jelgava, Latvia). 1828-1832. doi: 10.22616/ERDev2018.17.N414.

4. Dubrovskis, V., Plume, I. (2017, May). Biogas potential from damaged bread. Engineering for Rural Development. For results 16-th International Scientific Conference: Engineering for rural Development, ERD (May 24-26, 2017, Jelgava, Latvia). 437-442. doi: 10.22616/ERDev2017.16.N087.

5. Li, C. R., Mortelmaier, C., Winter, J., Gallert, C. (2015). Co-digestion of wheat and rye bread suspensions with sourcesorted municipal biowaste. Waste Management, 40, 63-71. doi: 10.1016/j.wasman.2015.03.024.

6. Yoon, Y., Lee, S., Kim, K., Jeon, T., Shin, S. (2018). Study of anaerobic co-digestion on wastewater treatment sludge and food waste leachate using BMP test.Journal of Material Cycles And Waste Management, 20(1), 283-292. doi: 10.1007/ s10163-017-0581-9. 
7. Menardo, S., Balsari, P. (2012). An analysis of the energy potential of anaerobic digestionof agricultural by-products and organic waste. BioEnergy Research, 5(3), 759-767. doi: 10.1007/s12155-012-9188-0.

8. Kafle, G. K., Kim, S. H., Sung, K. I. (2013). Ensiling of fish industry waste for biogas production: A lab scale evaluation of biochemical methane potential (BMP) and kinetics. Bioresource Technology, 127, 326-336. doi: 10.1016/j.biortech.2012.09.032.

9. Lee, H. J., Lee, S. C., Kim, J. D., Oh, Y. G., Kim, B. K., Kim, C. W., Kim, K. J. (2003). Methane production potential of feed ingredients as measured by in vitro gas test. Asian-Australasian Journal of Animal Sciences, 16(8), 1143-1150. doi: 10.5713/ajas.2003.1143.

10. Alagcan, D. G., Pratap, S. K., Alagcan, M. M., Ginasha, D. R., Tuivavalagi, N. S., Garg, S. K. (2012). Use of compact biogas plant for biogas production utilizing Waste foodmaterials, fruits, and vegetable peelings of high calorific contents. International Journal of Engineering, Science and Metallurgy, 2(1), 371-381.

11. Acharya, R. C., Mukundan, U. (2015). Effect of substrate variation on biomethane production at pilot scale. European Journal of Biotechnology and Bioscience, 3(4), 24-27.

12. Bee, S. T., Nithiyaa, M., Sin, L. T., Tee, T. T., Rahmat, A. R. (2013). Investigation of biogas production and its residue with fertilization effect from municipal waste. Pakistan Journal of Biological Sciences, 16, 1104-1112. doi: 10.3923/ pjbs.2013.1104.1112.

13. Murphy, J., Braun, R., Weiland, P., Wellinger, A. (2011). Biogas from Crop Digestion. IEA Bioenergy.

14. Vitanza, R., Cortesi, A., Gallo, V., Colussi, I., De Arana-Sarabia, M. E. (2016). Biovalorization of brewery waste by applying anaerobic digestion. Chemical and Biochemical Engineering Quarterly, 30(3), 351-357. doi: 10.15255/CABEQ.2015.2237.

15. Colussi, I., Cortesi, A., Gallo, V., Vitanza, R. (2016). Biomethanization of brewer's spent grain evaluated by application of the anaerobic digestion model No. 1. Environmental Progress \& S Sustainable Energy, 35(4), 1055-1060. doi: 10.1002/ ep.12326.

16. Bochmann, G., Drosg, B., Fuchsa, W. (2015). Anaerobic digestion of thermal pretreated brewers' spent grains. Environmental Progress and Sustainable Energy, 34(4), 1092-1096. doi: 10.1002/ep.12110.

17. Panjicko, M., Zupancic, G. D., Zelic, B. (2015). Anaerobic biodegradation of raw and pre-treated brewery spent grain utilizing solid state anaerobic digestion. Acta Chimica Slovenica, 62(4), 818-827. doi: 10.17344/acsi.2015.1534.

18. Panjicko, M., Zupancic, G. D., Fanedl, L., Loga, R. M., Tisma, M., Zelic, B. (2017). Biogas production from brewery spent grain as a mono-substrate in a two-stage process composed of soiid-state anaerobic digestion and granular biomass reactors. Journal Of Cleaner Prodaction, 66, 519-529. doi: 10.1016/j.jclepro.2017.07.197.

19. Jatunarachchi, T. S. S., Senaratne, A. U., De Alwis, A. (2006). Study of anaerobic digestion of brewery spent grains. International Energy Journal, 7(4), 279-287.

20. Wei, S., Bai, Z. H., Qin, W., Wu, Z. G., Jiang, R. F., Ma, L. (2018). Nutrient use efficiencies, losses, and abatement strategies for peri-urban dairy production systems. Journal of Environmental Management, 228, 232-238. doi: 10.1016/j.jenvman.2018.09.016.

21. Hirano, M. Y., Da Silva, C. L. (2018). Dairy cattle biogas usage in microturbines for energy generation and thermal exploitation. Engenharia Agricola, 38(4), 526-535. doi: 10.1590/1809-4430-Eng.Agric.v38n4p526-535/2018.

22. Lijo, L., Gonzalez-Garcia, S., Bacenetti, J., Moreira, M. T. (2017). The environmental effect of substituting energy crops for food waste as feedstock for biogasproduction. Energy, 137, 1130-1143. doi: 10.1016/j.energy.2017.04.137.

23. Bilandzija, N., Voca, N., Kricka, T., Jurisic, V., Matin, A. (2013). Biogas production on dairy farms: A Croatia case study. Mljekarstvo, 63(1), 22-29.

24. Samuna, I., Saeeda, R., Abbasa, M., Rehanb, M., Nizami, A.-S., Asam, Z.-ul-Z. (2017). Assessment of bioenergy production from solid waste. Energy Procedia, 142, 655-660. doi: 10.1016/j.egypro.2017.12.108.

25. Ohemeng-Ntiamoah, J., Datta, T. (2018). Evaluating analytical methods for the characterization of lipids, proteins and carbohydrates in organic substrates for anaerobic co-digestion. Bioresource Technology, 247, 697-704. doi: 10.1016/j. biortech.2017.09.154.

26. Malakhova, D. V., Egorova, M. A., Prokudina, L. I., Netrusov, A. I., Tsavkelova, E. A. (2015). The biotransformation of brewer's spent grain into biogas by anaerobic microbial communities. World Journal of Microbiology \& Biotechnology, 31(12), 2015-2023. doi: 10.1007/s11274-015-1951-x.

27. Oliveira, J. V., Alves, M. M., Costa, J. C. (2018). Biochemical methane potential of brewery by-products. Clean Technologies And Environmentral Polycy, 20(2), 435-440. doi: 10.1007/s10098-017-1482-2.

28. Mamchenkov, I. P., Potashov, A. I., Chernavin, A. S. (1964). Fertilizer Handbook. Moscow: Ear.

29. Vasiliev, V. A., Filippova, N. V. (1988). Handbook of Organic Fertilizers. Moscow: Rosagropromizdat.

30. GSTU 46.004-99. (1999). Wheat flour. Specifications Kyiv [in Ukrainian]. 
31. Gerasimenko, V. G., Gerasimenko, M. O., Melnichenko, O. M. (2004). Biotechnology. Bila Tserkva.

32. Schulz, H., Eder, B. (2006). Biogas practice. Basics, planning, plant construction, examples. Staufen near Freiburg, Germany: Okobuch Verlag.

33. Amon, T., von Bredov, H., Gromke, J. D., Doehler, H., Fisher, E., Frie, J., ... Woolf, S. (2005). Planning and installing bioenergy systems. A guide for installers, architects and engineers. Gyultsov-Pruzenm Germany: Special Renewable Resources Agency (FNR).

34. Karp, D. B. (2004). Econometrics. Vladivostok: DVGAU.

35. Förster, E., Rönz B. (1979). Methoden der Korrelations und Regressionsanalise. Berlin: Verlag die Wirstschaft.

36. The method of dividing a segment in half. URL: http:// https://math.semestr.ru/optim/dichotomy-minimum.php (Last accessed: 15.02.2019).

37. Zablodskiy, M., Savchenko, V., Sinyavsky, O., Pliuhin, V. (2018, April). Interactions Between Magnetic Field and Biological Objects of Plant Origin. Proceedings For results IEEE 38th International Conference on Electronics and Nanotechnology, ELNANO. (April 24-26, 2018, Kyiz, Ukraine). doi: 10.1109/ELNANO.2018.8477484.

Стаття надійшла до редакції / Received 27.03.19 Статтю прорецензовано / Revised 12.06.19

Статтю підписано до друку / Accepted 16.09.19

\section{В.М. Полішук, С.А. Шворов, С.Є. Тарасенко, С.О.Антипов}

Національний університет біоресурсів і природокористування України, вул. Героїв Оборони, 12, Київ, 03041, Україна, +38044527 8748, term_chair@nubip.edu.ua

\section{ПІДВИЩЕННЯ ВИХОДУ БІОГАЗУ ПРИ ЗБРОДЖУВАННІ ГНОЮ ВЕЛИКОЇ РОГАТОЇ ХУДОБИ НА ОСНОВІ РАЦІОНАЛЬНОГО ДОДАВАННЯ НЕКОНДИЦЙНОГО БОРОШНА В ЯКОСТІ КОСУБСТРАТУ}

Вступ. Важливим господарським питанням є переробка відходів тваринництва і сільськогосподарського виробництва не тільки для покращення екологічної безпеки, а й для отримання енергетичних ресурсів.

Проблематика. Коров'ячий гній застосовується для отримання біогазу, однак його вихід при цьому відносно низький. Одним із шляхів підвищення виходу є спільне зброджування коров'ячого гною з некондиційним борошном, яке не можна використовувати як продукт харчування для людини та як корм для сільськогосподарських тварин. Проте вміст його в субстраті, при якому вихід біогазу є максимальним і не відбувається інгібування процесу метанового бродіння, не визначено.

Мета. Підвищення виходу біогазу шляхом раціонального додавання некондиційного борошна до субстрату на основі коров'ячого гною.

Матеріали й методи. Дослідження виходу біогазу при метановому зброджуванні субстрату на основі коров'ячого гною з додаванням некондиційного борошна здійснювали на біогазовій установці у складі метантенка робочим об’ємом 30 л і мокрого газгольдера при періодичному режимі завантаження субстрату і температурі бродіння $35{ }^{\circ} \mathrm{C}$. Порція субстрату: 1,7 кг гною, 2,5 кг води та 50, 100, 250 або 500 г борошна. При цьому склад борошна в субстраті становив $1,2,2,3 \%, 5,6 \%$ та 10,6 \%. Для визначення оптимального вмісту борошна в субстраті, за умови максимального виходу біогазу, було застосовано метод дихотомії.

Результати. Максимальний вихід біометану при вмісті 1,2 \% борошна в субстраті становить 14,3 л/кг сухої органічної речовини (СОР), при 2,3 \% - 20,9 л/кг СОР, при 5,6 \% - 19,2 л/кг СОР. При вмісті 10,6 \% борошна в субстраті біогаз не горів, бродіння швидко припинялося. Оптимальний вміст борошна в субстраті на основі коров'ячого гною, при якому вихід біогазу збільшується в 1,5 рази, становить 3,7 \%.

Висновки. На основі проведених експериментальних досліджень побудовано модель виходу біогазу при поступовому завантаженні субстрату та визначено оптимальний вміст борошна в субстраті, при якому забезпечується максимальний вихід біогазу.

Ключові слов а: біогаз, метантенк, некондиційне борошно, гній великої рогатої худоби, біогазова установка, метанове бродіння. 